Acta vet. scand. 1984, 25, 57-66.

From the Department of Obstetrics and Gynaecology and the Department of Clinical Chemistry, Swedish University of Agricultural Sciences, Uppsala, Sweden.

\title{
SFMINAL CHANGES IN BOARS AFTER HEAT STRESS
}

\author{
By \\ Kjell Larsson and Stig Einarsson
}

\begin{abstract}
LARSSON, KJELL and STIG EINARSSON: Seminal changes in boars after heat stress. Acta vet. scand. 1984, 25, 57-66. - The object of the present study was to investigate the influence of elevated ambient temperature on sperm production, sperm morphology and composition of seminal plasma in boars. A total of 8 boars were used, 4 of them were exposed to $35^{\circ} \mathrm{C}$, in a climate room, during $100 \mathrm{~h}$ and 4 served as controls and were kept at $20^{\circ} \mathrm{C}$ during $100 \mathrm{~h}$ in the climate room.

Ejaculate volume and total sperm count per ejaculate remained unaltered. An obvious decrease in sperm motility was seen in all heat exposed boars $15-21$ days after the exposure. The most consistent increase in sperm abnormalities were proximal cytoplasmic droplets and abnormal sperm heads. The highest levels were found during the 4th week after exposure. All the sperm characteristics assessed had returned to normal levels at the end of the experimental period, which means 7-8 weeks after the end of exposure.

Only minor and inconsistent alterations were found in the seminal plasma components analysed and these changes were observed both in control and experimental boars.
\end{abstract}

boars; elevated ambient temperature; sperm morphology; semen biochemistry.

Exposure of boars to elevated ambient temperature has been reported to cause lowered fertility (Wetteman et al. 1977), decreased ejaculate volumes, total sperm counts and percentages of motile spermatozoa, and increased numbers of abnormal spermatozoa (McNitt \& First 1970, Wetteman et al. 1977). Einarsson (1968) found lowered ejaculate volumes and reduced fertility of Swedish AI-boars that had been kept outdoors during the warm summer period. Similar results were reported of Thibault et al. (1966) and by Signoret $\& d u$ Mesnil du Buisson (1968). 
McNitt et al. (1972) found the normal testicular temperature of boars to be $35.7^{\circ} \mathrm{C}$ and the scrotum surface temperature was $33.1^{\circ} \mathrm{C}$. Exposure of the boars to $40^{\circ} \mathrm{C}$ for 80 min caused a significant increase of the testicular temperature.

Local heating of the scrotum causes disturbances in spermiogenesis resulting in lowered sperm concentration, lowered percentages of motile spermatozoa and increased numbers of abnormal sperm cells (Holst 1949, Mazzari et al. 1968). The aforementioned studies indicate that exposure of boars to elevated ambient temperature causes similar morphological alterations in the ejaculates. The effects on accessory sex gland function have received little attention.

The aim of the present study was to investigate the influence of elevated ambient temperature on sperm production, sperm morphology and composition of seminal plasma in boars.

\section{MATERIAL AND METHODS}

Eight sexually mature Swedish Landrace boars were used in the study. The boars were brought to the clinic at approximately 7 months of age. At the clinic they were kept in individual pens, the ambient temperature being approximately $18^{\circ} \mathrm{C}$. The boars were fed a conventional diet and none of them showed clinical signs of disease. Semen was collected twice weekly from all boars and all boars produced at least 8 ejuculates with normal sperm morphology, according to the standards of our laboratory, before exposure to elevated temperature.

Ten days before heat stress permanent vein catheters were inserted into one of the brachial veins according to the method of Karlbom et al. (1982). Blood samples were drawn at regular intervals through the cannulas during the whole experimental periods. The results from the hormone analyses have been published elsewhere (Larsson et al. 1983).

The boars were exposed to elevated temperature in a temperature controlled room (climate room) which was about $2.8 \mathrm{~m}$ square i.e. somewhat larger than the original pens. Duration of exposure was $100 \mathrm{~h}$ and the boars were then returned to their original pens. Four boars (experimental group) were exposed to $35^{\circ} \mathrm{C}$ and $40 \%$ relative humidity and 4 boars (control group) were kept in the climate room at $20^{\circ} \mathrm{C}$ and $60-70 \%$ relative humidity. Semen collections were not performed in the climate room. 
Semen collections were performed by the gloved-hand technique and the boars were allowed to mount the dummy sow in their own pens. At collction the gel portion of the ejaculate was filtered away through double gauze and the remaining part of the ejaculate was collected into a plastic bag in a preheated vacuumflask. Ejaculate volumes were measured in graded glass cylinders, sperm motility was estimated in a phase-contrast microscope at $37^{\circ} \mathrm{C}$ and at a maximum of $\times 400$ magnification. Sperm morphology was assessed by phase-contrast microscopy of formol-saline fixed wet preparations (Hancock 1957, Bane 1961) and by light microscopy of Williams-stained dry smears (Lagerlöf 1934). Sperm concentration was measured by haemocytometric counting. Within 10 min after semen collection $20 \mathrm{ml}$ of each ejaculate was centrifuged for $20 \mathrm{~min}$, the seminal plasma was then analysed for fructose and the remaining part of the seminal plasma was stored at $-20^{\circ} \mathrm{C}$ until analysed for concentrations of sodium, potassium, magnesium, chloride and total protein. The methods used for the biochemical analyses were the same as previously used by Einarsson (1971).

All the boars were slaughtered at the end of the experimental period. The sexual organs were collected as soon as possible after slaughter. All sexual organs were carefully examined macroscopically. Specimen from each testicle were fixed in Bouin's fluid for histological examination. The pieces of tissue were dehydrated, embedded in paraffin, sectioned and stained with haemalum-eosin and van Gieson's haemalum picrotocin.

\section{RESULTS}

The results of the study are summarized in Tables $1-5$. The values referred to as "before" represent mean and standard deviations for 8 ejaculates from each boar. The associated figures in the tables represent the number of boars, with a measured value different from the mean \pm 2 s of the 8 ejuculates collected before exposure, on the particular occasion. Thus the comparisons between "before" and "after" exposure were made within boars and as combined figures for all boars.

Ejaculate volume, total sperm count per ejaculate and percentage of motile spermatozoa are presented in Table 1. No consistent differences in ejaculate volume and sperm count per 
Table 1. Ejaculate volume, total sperm count per ejaculate and per cent motile spermatozoa in boars before and after treatment in climate room. The associated figures indicate numbers of boars with a measured value different from the mean $\pm 2 \mathrm{~s}$ of the ejaculates collected before exposure.

\begin{tabular}{|c|c|c|c|c|c|c|}
\hline \multirow{3}{*}{$\begin{array}{l}\text { Days after } \\
\text { exposure }\end{array}$} & \multirow{2}{*}{\multicolumn{2}{|c|}{$\frac{\text { Volume }(\mathrm{ml})}{\text { Temp in climate room }}$}} & \multirow{2}{*}{\multicolumn{2}{|c|}{$\begin{array}{c}\text { Total sperm count }\left(\mathrm{x}^{10^{9}}\right) \\
\text { Temp in climate room }\end{array}$}} & \multirow{2}{*}{\multicolumn{2}{|c|}{$\frac{\text { Motility }(\%)}{\text { Temp in climate roon }}$}} \\
\hline & & & & & & \\
\hline & $35^{\circ} \mathrm{C}$ & $20^{\circ} \mathrm{C}$ & $35^{\circ} \mathrm{C}$ & $20^{\circ} \mathrm{C}$ & $35^{\circ} \mathrm{C}$ & $20^{\circ} \mathrm{C}$ \\
\hline Before & $167 \pm 26$ & $135 \pm 15$ & $45.5 \pm 12.2$ & $38.7 \pm 6.8$ & $74 \pm 2$ & $73 \pm 8$ \\
\hline $1-7$ & 173 & 152 & 55.0 & $\left.55.3^{2}\right)$ & $\left.69^{1}\right)$ & 71 \\
\hline $8-14$ & 204 & $\left.172^{2}\right)$ & $\left.56.9^{1}\right)$ & $\left.51.6^{1}\right)$ & $\left.68^{2}\right)$ & 73 \\
\hline $15-21$ & 179 & $\left.163^{2}\right)$ & 55.5 & $\left.49.4^{1}\right)$ & $\left.57^{4}\right)$ & 74 \\
\hline $22-28$ & 185 & $\left.154^{1}\right)$ & 51.7 & $\left.55.1^{1}\right)$ & $\left.57^{2}\right)$ & 75 \\
\hline $29-35$ & 169 & 128 & $\left.57.1^{1}\right)$ & $\left.63.1^{1}\right)$ & $\left.66^{2}\right)$ & 75 \\
\hline $36-42$ & 174 & & 50.2 & & $\left.7^{1}\right)$ & \\
\hline $43-49$ & 176 & & $\left.55.2^{2}\right)$ & & 71 & \\
\hline $50-56$ & 196 & & $\left.69.8^{1}\right)$ & & 74 & \\
\hline
\end{tabular}

ejaculate were observed within or between control boars and experimental boars, respectively, throughout the experimental period. The percentages of motile spermatozoa remained on preexposure levels in the control boars. In the ejaculates from the experimental boars an obvious decrease in sperm motility was seen in all 4 boars 15-21 days after the exposure. In 2 of these boars sperm motility was lowered already 8 days after exposure. The motility had returned to "before exposure" values in all 4 boars at day 43 .

Tables 2 and 3 present the sperm morphology in the ejaculates before and after exposure. The most consistent increases of sperm abnormalities were proximal cytoplasmic droplets and abnormal sperm heads. Only minor or inconsistent increases of the other sperm abnormalities were observed in the experimental boars. No deviations in sperm morphology were seen in any of the control boars. The incidence of proximal cytoplasmic droplets increased continously and was highest during the 4th week after exposure and thereafter decreased. The incidence of abnormal sperm heads started to increase markedly $15-21$ days after exposure reaching its highest level at days $22-28$. All the sperm characteristics assessed had returned to "before" levels at the end of the experimental period. 
T a b l e 2. Proximal cytoplasmic droplets, defective middle-pieces and bent or coiled tails in boars before and after treatment in climate room. The associated figures indicate number of boars with a measured value different from the mean $\pm 2 \mathrm{~s}$ of the ejaculates collected before exposure.

\begin{tabular}{|c|c|c|c|c|c|c|}
\hline \multirow{2}{*}{$\begin{array}{l}\text { Days after } \\
\text { exposure }\end{array}$} & \multicolumn{2}{|c|}{$\frac{\text { Prox cytopl droplets }(\%)}{\text { Temp in climate room }}$} & \multicolumn{2}{|c|}{$\frac{\text { Defective middle-pieces }(\%)}{\text { Temp in climate room }}$} & \multicolumn{2}{|c|}{$\begin{array}{l}\text { Bent or coiled tails }(\%) \\
\text { Temp in climate room }\end{array}$} \\
\hline & $35^{\circ} \mathrm{C}$ & $20^{\circ} \mathrm{C}$ & $35^{\circ} \mathrm{C}$ & $20^{\circ} \mathrm{C}$ & $35^{\circ} \mathrm{C}$ & $20^{\circ} \mathrm{C}$ \\
\hline Before & $1.6 \pm 1.6$ & $0.9 \pm 0.7$ & $1.9 \pm 1.1$ & $2.4 \pm 2.4$ & $0.8 \pm 0.6$ & $0.3 \pm 0.3$ \\
\hline $1-7$ & $\left.5.8^{1}\right)$ & 1.0 & 1.3 & 1.8 & 0.8 & 0.6 \\
\hline $8-14$ & $\left.13.3^{3}\right)$ & 0.7 & 1.6 & 1.4 & 1.1 & 0.2 \\
\hline $15-21$ & $\left.22.4^{2}\right)$ & 0.8 & $\left.2.6^{1}\right)$ & 1.3 & 2.8 & 0.2 \\
\hline $22-28$ & $\left.23.9^{3}\right)$ & 0.3 & $\left.3.5^{2}\right)$ & 1.8 & 4.1 & 0.4 \\
\hline $29 \_35$ & $\left.8.7^{2}\right)$ & 0.3 & $\left.2.1^{1}\right)$ & 0.9 & 1.8 & 1.6 \\
\hline $36-42$ & $\left.4.9^{1}\right)$ & & $\left.1.8^{1}\right)$ & & 0.8 & \\
\hline $43-49$ & $\left.6.0^{2}\right)$ & & 0.8 & & 0.5 & \\
\hline $50-56$ & 3.5 & & 0.8 & & 0.5 & \\
\hline
\end{tabular}

T a ble 3. Abnormal sperm heads, acrosome defects and tailless heads in boars before and after treatment in climate room. The associated figures indicate number of boars with a measured value different from the mean $\pm 2 \mathrm{~s}$ of the ejaculates collected before exposure.

\begin{tabular}{|c|c|c|c|c|c|c|}
\hline \multirow{3}{*}{$\begin{array}{l}\text { Days after } \\
\text { exposure }\end{array}$} & \multirow{2}{*}{\multicolumn{2}{|c|}{$\frac{\text { Abnorm sperm heads }(\%)}{\text { Temp in climate room }}$}} & \multirow{2}{*}{\multicolumn{2}{|c|}{$\begin{array}{l}\text { Acrosome defects }(\%) \\
\text { Temp in climate room }\end{array}$}} & \multirow{2}{*}{\multicolumn{2}{|c|}{$\frac{\text { Tailless heads (\%) }}{\text { Temp in climate room }}$}} \\
\hline & & & & & & \\
\hline & $35^{\circ} \mathrm{C}$ & $20^{\circ} \mathrm{C}$ & $35^{\circ} \mathrm{C}$ & $20^{\circ} \mathrm{C}$ & $35^{\circ} \mathrm{C}$ & $20^{\circ} \mathrm{C}$ \\
\hline Before & $2.0 \pm 0.4$ & $2.6 \pm 0.7$ & $1.8 \pm 1.0$ & $2.5 \pm 1.6$ & $0.3 \pm 0.2$ & $0.3 \pm 0.3$ \\
\hline $1-7$ & 1.3 & 2.5 & 0.6 & 2.5 & 0.1 & 0.5 \\
\hline $8-14$ & 2.3 & 3.2 & 0.8 & 2.5 & 1.1 & 0.2 \\
\hline $15-21$ & $\left.19.4^{3}\right)$ & 1.8 & $\left.4.0^{2}\right)$ & 0.9 & $\left.0.9^{2}\right)$ & 0.3 \\
\hline $22-28$ & $\left.20.2^{4}\right)$ & 1,8 & $\left.7.3^{1}\right)$ & 0.9 & $\left.1.2^{1}\right)$ & 0.1 \\
\hline $29-35$ & $\left.5.3^{3}\right)$ & 2.4 & 2.1 & 0.3 & 0.2 & 0.2 \\
\hline $36-42$ & $\left.3.4^{1}\right)$ & & 1.5 & & 0.2 & \\
\hline $43-49$ & 2.6 & & 0.5 & & 0.5 & \\
\hline $50-56$ & 2.0 & & 0.5 & & 0.3 & \\
\hline
\end{tabular}

The results of the seminal plasma analyses are presented in Tables 4-5. Only minor and inconsistent alterations were found in the seminal plasma components and these changes were observed both in control boars and in experimental boars.

The morphological examination of the testicular tissues revealed no lesions in the experimental boars or in the control boars. 
T a ble 4. Sodium, potassium and chloride in seminal plasma in boars before and after treatment in climate room. The associated figures indicate number of boars with a measured value different from the mean $\pm 2 \mathrm{~s}$ of the ejaculates collected before exposure.

\begin{tabular}{|c|c|c|c|c|c|c|}
\hline \multirow{3}{*}{$\begin{array}{l}\text { Days after } \\
\text { exposure }\end{array}$} & \multirow{2}{*}{\multicolumn{2}{|c|}{$\frac{\text { Sodium }(\mathrm{mmol} / \mathrm{l})}{\text { Temp in climate room }}$}} & \multirow{2}{*}{\multicolumn{2}{|c|}{$\frac{\text { Potassium (mmol/l) }}{\text { Temp in climate room }}$}} & \multirow{2}{*}{\multicolumn{2}{|c|}{$\begin{array}{l}\text { Chloride }(\mathrm{mmol} / \mathrm{l}) \\
\text { Temp in climate room }\end{array}$}} \\
\hline & & & & & & \\
\hline & $35^{\circ} \mathrm{C}$ & $20^{\circ} \mathrm{C}$ & $35^{\circ} \mathrm{C}$ & $20^{\circ} \mathrm{C}$ & $35^{\circ} \mathrm{C}$ & $20^{\circ} \mathrm{C}$ \\
\hline Before & $130.8 \pm 3.1$ & $130.8 \pm 6.0$ & $13.9 \pm 0.4$ & $14.0 \pm 0.9$ & $104.9 \pm 5.3$ & $106.2 \pm 8.7$ \\
\hline $1-7$ & 131.1 & 130.1 & $\left.14.4^{1}\right)$ & $\left.14.6^{1}\right)$ & 104.8 & $\left.103.8^{1}\right)$ \\
\hline $8-14$ & 131.8 & 131.9 & 13.7 & 14.0 & 106.0 & 107.1 \\
\hline $15-21$ & 130.1 & 133.6 & $\left.14.3^{1}\right)$ & 14.0 & 106.5 & 108.1 \\
\hline $22-28$ & 129.6 & $\left.140.8^{1}\right)$ & $\left.14.0^{2}\right)$ & $\left.14.6^{1}\right)$ & $\left.102.9^{2}\right)$ & $\left.117.0^{1}\right)$ \\
\hline $29-35$ & $\left.136.1^{1}\right)$ & 131.3 & $\left.15.2^{2}\right)$ & $\left.14.7^{1}\right)$ & $\left.106.0^{1}\right)$ & $\left.104.7^{1}\right)$ \\
\hline $36-42$ & 127.3 & & 14.4 & & 101.1 & \\
\hline $43-49$ & $\left.127.0^{1}\right)$ & & 14.6 & & $\left.100.3^{1}\right)$ & \\
\hline $50-56$ & $\left.140.7^{1}\right)$ & & $\left.16.1^{2}\right)$ & & $\left.115.8^{1}\right)$ & \\
\hline
\end{tabular}

Ta b le 5. Fructose, magnesium and total protein in seminal plasma in boars before and after treatment in climate room. The associated figures indicate number of boars with a measured value different from the mean $\pm 2 \mathrm{~s}$ of the ejaculates collected before exposure.

\begin{tabular}{|c|c|c|c|c|c|c|}
\hline \multirow{3}{*}{$\begin{array}{l}\text { Days after } \\
\text { exposure }\end{array}$} & \multirow{2}{*}{\multicolumn{2}{|c|}{$\begin{array}{l}\text { Fructose (mg/ejaculate) } \\
\text { Temp in climate room }\end{array}$}} & \multirow{2}{*}{\multicolumn{2}{|c|}{$\begin{array}{l}\text { Magnesium }(\mathrm{mmol} / \mathrm{l}) \\
\text { Temp in climate room }\end{array}$}} & \multirow{2}{*}{\multicolumn{2}{|c|}{$\frac{\text { Total protein }(\mathrm{g} / \mathrm{l})}{\text { Temp in climate room }}$}} \\
\hline & & & & & & \\
\hline & $35^{\circ} \mathrm{C}$ & $20^{\circ} \mathrm{C}$ & $35^{\circ} \mathrm{C}$ & $20^{\circ} \mathrm{C}$ & $35^{\circ} \mathrm{C}$ & $20^{\circ} \mathrm{C}$ \\
\hline Before & $31.4 \pm 18.3$ & $41.2 \pm 41.6$ & $4.93 \pm 0.23$ & $4.10 \pm 1.77$ & $16.9 \pm 2.4$ & $15.1 \pm 3.9$ \\
\hline $1-7$ & $\left.33.6^{1}\right)$ & 38.7 & $\left.4.91^{1}\right)$ & $\left.4.26^{1}\right)$ & 16.4 & 16.1 \\
\hline $8-14$ & $\left.54.7^{1}\right)$ & $\left.40.2^{1}\right)$ & 4.55 & 3.95 & 16.4 & 14.9 \\
\hline $15 \longrightarrow 21$ & $\left.48.5^{1}\right)$ & $\left.39.3^{2}\right)$ & 5.01 & $\left.3.73^{1}\right)$ & 17.0 & 14.9 \\
\hline $22-28$ & $\left.35.7^{1}\right)$ & 15.1 & $\left.5.21^{1}\right)$ & 3.68 & $\left.17.9^{1}\right)$ & 15.6 \\
\hline $29-35$ & 36.8 & 16.5 & $\left.5.98^{2}\right)$ & $\left.2.58^{2}\right)$ & $\left.21.6^{2}\right)$ & 12.8 \\
\hline $36-42$ & $\left.23.3^{1}\right)$ & & 5.00 & & $\left.18.4^{1}\right)$ & \\
\hline $43-49$ & $\left.18.8^{1}\right)$ & & 4.97 & & 18.4 & \\
\hline $50-56$ & $\left.30.2^{1}\right)$ & & 4.48 & & $\left.17.3^{1}\right)$ & \\
\hline
\end{tabular}

\section{DISCUSSION}

During the post-exposure period neither total sperm counts nor ejaculate volumes of the boars were altered. McNitt \& First (1970) found decreased sperm numbers in the ejaculates after heat exposure. The most evident changes were measured 28-32 days after exposure. The variations between ejaculates within 
boars were great in the present study. It is therefore likely, that small variations due to treatment have been overlooked.

The lowered motility and the morphological alterations of the ejaculated spermatozoa for the boars that were exposed to elevated ambient temperature are in accordance with earlier studies (e.g. Holst 1949, Mazzari et al. 1968, McNitt \& First 1970, Einarsson \& Larsson 1982). However, since only minor and inconsistent alterations were found in spermatozoa from boars that were exposed for $24 \mathrm{~h}$ in the same climate room (Einarsson $\&$ Larsson 1982), it is likely that the duration of exposure is of importance for the disturbances. Alterations in the sperm morphology were found already 8 days after the end of the $100 \mathrm{~h}$ exposure, indicating that the epididymal influence on sperm maturation had been disturbed. The most consistent increase was found in the percentage of spermatozoa with proximal cytoplasmic droplets. According to Holst (1949) the first sign of disturbance in the spermiogenesis in the boar is an increased incidence of proximal cytoplasmic droplets. The migration of the cytoplasmic droplet normally takes place in a narrow region of the caput epididymis (Gustafsson et al. 1970) and the continous increase of spermatozoa with proximal cytoplasmic droplets might therefore indicate a disturbed epidimymal function. However, the percentages of spermatozoa with single-bent or coiled tails, an indicator of epididymal function (Einarsson \& Gustafsson 1973, Bonte et al. 1978) were low throughout the experimental period. Thus, the exposure to elevated temperature did not induce a genuine epididymal dysfunction. The cause of the morphological changes of the spermatozoa, which appeared very early after heat exposure, might be that epididymal function is partly affected by scrotum temperature and/or by he hormonal changes that occur during and after exposure to elevated ambient temperature (Larsson et al. 1983).

In the boars that were exposed to elevated ambient temperature the incidence of abnormal sperm heads increased during the postexposure period, indicating a disturbed spermiogenesis. It might be postulated that all spermatozoa collected $\leq 7$ days after the end of exposure to elevated ambient temperature had left the testicles already at the beginning of exposure, while very few of the spermatozoa collected 15-21 days after exposure had left the testicles during exposure (Swierstra 1968). Only in 2 of the 4 boars were very high percentages of abnormal sperm heads 
found. In these 2 cases were also the incidences of proximal cytoplasmic droplets very high. No indication of a decreased sperm production was found in any boar in the present investigation. The testicular disturbance must therefore be considered as slight or moderate but in no case severe. All the sperm characteristics measured had returned to normal levels at the end of the experimental period. Furthermore no lesions were observed in the testicular tissues collected at the end of the experimental period, which indicate that a complete regeneration already had taken place.

The results of the analyses of the concentrations of the seminal plasma components before and after heat exposure did not indicate any changes. The non-responces of the levels of total protein and fructose to the treatment might indicate that neither the decreased testosterone levels during the heat exposure nor the elevated testosterone levels during the first 5 days after heat exposure did influence the activity of the accessory sex glands. Identical results were presented by Egbunike \& Jeyakumar (1980). In their study boars, adapted to natural tropical conditions, were subjected to direct heat stress by exposure to direct sunlight. The seminal plasma protein content and the fructose levels remained unchanged. The protein profile was however different between heat-stressed boars and control boars. As the quality of the proteins in the seminal plasma was not evaluated in the present study it is impossible to certify that the accessory glands were unaffected by the heat exposure.

\section{ACKNOWLEDGEMENTS}

This investigation was supported by the Swedish Council for Forestry and Agricultural Research. The authors wish to acknowledge the valuable technical assistance given by Mari-Anne Carlsson, Kerstin Lindblad, Karin Selin-Wretling and the staff at the department's stable.

\section{REFERENCES}

Bane, A.: Acrosomal abnormality associated with sterility in boar. IVth Int. Congr. Anim. Reprod., The Hague 1961, vol. 4, 810817.

Bonte, P., M. Vandeplassche \& A. Sagane: Functional epididymal dissorders in boars. Zuchthygiene 1978, 13, 161_-175

Egbunike, G. N.\& L. H. Jeyakumar: Some biochemical characteristics of porcine seminal plasma under stressful hot humid climate conditions. Zbl. Vet. Med. A 1980, 27, 555—562. 
Einarsson, S.: Factors affecting fertility in artificial insemination of swine. Nord. Vet.-Med. 1968, 20, 622-629.

Einarsson, S.: Studies on the composition of epididymal content and semen in the boar. Acta vet. scand. 1971, 11, suppl. 36, $80 \mathrm{pp}$.

Einarsson, S. \& B. Gustafsson: A case of epididymal dysfunction in boar. Andrologie 1973, 5. 273-279.

Einarsson, S. \& K. Larsson: Exposure of boars to elevated ambient temperature: morphological studies of the ejaculated semen. Proc. I.P.V.S. Congr., Mexico 1982, p. 215.

Gustafsson, B., B. Crabo \& S. Einarsson: Morphology of the spermatozoa and composition of the plasma in the boar epididymis. Proc. 11th Nord. Vet. Congr., Bergen 1970, p. 241.

Hancock, J. L.: The morphology of boar spermatozoa. J. R. microsc. Soc. $1957,76,84-97$.

Holst, S. J.: Sterility in boars. Nord. Vet.-Med. 1949, 1, 87-120.

Karlbom, I., S. Einarsson \& L.-E. Edqvist: Attainment of puberty in female pigs: Clinical appearance and patterns of progesterone, oestradiol-17 $\beta$ and LH. Anim. Reprod. Sci. 1982, 4, 301-312.

Lagerlöf, N.: Morphologische Untersuchungen über Veränderungen im Spermabild un in den Hoden bei Bullen mit verminderter oder aufgehobener Fertilität. (Morphological studies of changes in the semen picture and the testicles in bulls with lowered fertility or sterility). Acta path. microbiol. scand. 1934, suppl. 19, 254 pp.

Larsson, K., S. Einarsson, K. Lundström \& J. Hakkarainen: Endocrine effects of heat stress in boars. Acta vet. scand. 1983, 24, 305314.

Mazzari, G., F. du Mesnil du Buisson \& R. Ortavant: Action de la température et de la lumière sur la spermatogenèse, la production et le pouvoir fécondant du sperme chez le verrat. (Action of temperature and light on spermatogenesis, sperm production and fertility of the boar). Proc. VIth Int. Congr. Anim. Reprod. \& A.I., Paris, 1968, I, 305-308.

McNitt, J. I. \& N. L. First: Effects of 72 hour heat stress on semen quality in boars. Int. J. Biometeor. 1970, 14, 373-380.

McNitt, J. I., C. B. Tanner \& N. L. First: Thermoregulation in the scrotal system of the boar. I. Temperature distribution. J. Anim. Sci. 1972, 34, 112-116.

Signoret, J. P. \& F. du Mesnil du Buisson: Influence des conditions d'habitat du verrat sur la fécondance du sperme. (Influence of the housing conditions of boars on the fertility of the spermatozoa). Proc. VIth Int. Congr. Anim. Reprod. \& A.I., Paris, 1968, I, 317-319.

Swierstra, E. E.: Cytology and duration of the cycle of the seminiferous epithelium of the boar; duration of spermatozoan transit through the epididymis. Anat. Rec. 1968, 161, 171-186.

Thibault, C., M. Courot, L. Martinet, P. Mauleon, F. du Mesnil du Buisson, R. Ortavant, J. Pelletier \& J. P. Signoret: Regulation of breeding season and estrous cycles by light and external stimuli in some mammals. J. Anim. Sci. 1966, 25, suppl. 1, 119-142. 
Wettemann, R. P., M. E. Wells, L. W. Brock, R. K. Johnson, R. Harp \& $R$. Vencl: Recovery of normal semen quality after heat stress of boars. Oklahoma Agric. Exp. Stn. Anim. Sci. Res. Rpt. 1977, $152-156$.

\section{SAMMANFATTNING}

Spermaförändringar av värmestress hos galtar.

Ändamålet med denna undersökning var att studera inverkan av förhöjd omgivningstemperatur på spermaproduktion, sperimiemorfologi och spermaplasmans sammansättning hos galtar. Totalt ingick 8 galtar i försöket. Fyra av dem exponerades för $35^{\circ} \mathrm{C}$ under 100 timmar i en klimatkammare, medan 4 galtar användes som kontroller med $20^{\circ} \mathrm{C}$ temperatur under 100 timmar i klimatkammare.

Ejakulatvolym och totalantal spermier per ejakulat påverkades inte. Spermiemotiliteten sjönk hos alla galtar som utsattes för värmestress och var lägst 15-21 dagar efter värmestressen. De mest påtagliga förändringarna i spermiemorfologin var förhöjda frekvenser proximala cytoplasmadroppar och spermiehuvuddefekter. De högsta nivåerna återfanns under $4: \mathrm{e}$ veckan efter värmestressen. Spermiemorfologin hade normaliserats vid slutet av försöksperioden dvs 7-8 vecor efter värmestressen.

Spermaplasmans sammansättning var i stort sett oförändrad under hela försöksperioden. Mindre förändringar observerades hos såväl kontrollgaltar som försöksgaltar.

\section{(Received January 12, 1984).}

Reprints may be requested from: Kjell Larsson, the Department of Obstetrics and Gynaecology, Swedish University of Agricultural Sciences, S-750 07 Uppsala, Sweden. 